\title{
Unraveling the time-dependent relevance of input model uncertainties for a lumped hydrologic model of a pre-alpine karst system
}

\author{
Daniel Bittner ${ }^{1,2}$ (D) Beatrice Richieri ${ }^{1} \cdot$ Gabriele Chiogna ${ }^{1,3}$ \\ Received: 18 January 2021 / Accepted: 24 June 2021 / Published online: 21 July 2021 \\ (C) The Author(s) 2021
}

\begin{abstract}
Uncertainties in hydrologic model outputs can arise for many reasons such as structural, parametric and input uncertainty. Identification of the sources of uncertainties and the quantification of their impacts on model results are important to appropriately reproduce hydrodynamic processes in karst aquifers and to support decision-making. The present study investigates the timedependent relevance of model input uncertainties, defined as the conceptual uncertainties affecting the representation and parameterization of processes relevant for groundwater recharge, i.e. interception, evapotranspiration and snow dynamic, on the lumped karst model LuKARS. A total of nine different models are applied, three to compute interception (DVWK, Gash and Liu), three to compute evapotranspiration (Thornthwaite, Hamon and Oudin) and three to compute snow processes (Martinec, Girons Lopez and Magnusson). All the input model combinations are tested for the case study of the Kerschbaum spring in Austria. The model parameters are kept constant for all combinations. While parametric uncertainties computed for the same model in previous studies do not show pronounced temporal variations, the results of the present work show that input uncertainties are seasonally varying. Moreover, the input uncertainties of evapotranspiration and snowmelt are higher than the interception uncertainties. The results show that the importance of a specific process for groundwater recharge can be estimated from the respective input uncertainties. These findings have practical implications as they can guide researchers to obtain relevant field data to improve the representation of different processes in lumped parameter models and to support model calibration.
\end{abstract}

Keywords Conceptual models · Input uncertainties $\cdot$ Groundwater recharge $\cdot$ Karst $\cdot$ Rainfall-runoff

\section{Introduction}

Hydrologic models serve as important tools for the assessment of dominant hydrodynamic processes in karst systems (Hartmann et al. 2013; Sivelle et al. 2019). In those models, subsurface heterogeneity and the resulting complex hydrodynamic processes typical for karst aquifers are often represented in a simplified way (Fleury et al. 2007; Guinot et al. 2015;

Daniel Bittner

daniel.bittner@tum.de

1 Faculty of Civil, Geo and Environmental Engineering, Technical University of Munich, Arcisstr. 21, 80333 Munich, Germany

2 Erftverband, Department for River Basin Management, Am Erftverband 6, 50126 Bergheim, Germany

3 Institute of Geography, University of Innsbruck, Innrain 52, 6020 Innsbruck, Austria
Sivelle et al. 2021; Sivelle and Jourde 2020). The assessment of the reliability of a model output is therefore an important step towards an improved description of the karst system (Hartmann et al. 2014a). This assessment is usually done by uncertainty quantification techniques, which investigate the likelihood of a model outcome while considering the unknowns in a hydrologic model (Sarrazin et al. 2018; Teixeira Parente et al. 2019). These unknowns arise from different sources of uncertainties, i.e. structural (Fandel et al. 2020; Henson et al. 2018), parametric (Mazzilli et al. 2012; Moussu et al. 2011) and input uncertainties (Liu et al. 2018; Nerantzaki et al. 2020).

Structural uncertainties evolve from the simplifications required while creating a conceptual model of a real-world system (Gupta and Govindaraju 2019; Rojas et al. 2008). This conceptualization often neglects certain parts of the natural system due to a lack of knowledge, which can lead to an underrepresentation of important hydrodynamic processes (Butts et al. 2004; Lee et al. 2011). Parametric uncertainties arise from the fact that the exact values of model parameters, such as discharge 
coefficients and storage thresholds, are often not known (Ahmadi et al. 2019; Hu et al. 2019). This is particularly true for lumped conceptual models, whose parameters cannot often be constrained by physical field experiments (Wagener et al. 2003). Hence, for each parameter, a reasonable parameter range needs to be defined in which the true parameter value is located (Seibert 1997). Finally, input uncertainties exist due to missing and/or uncertain input data (Breinl 2016; McMillan et al. 2012) as well as due to simplifications of the processes that finally represent the model input, e.g. the groundwater recharge (Kavetski et al. 2006; Patil et al. 2011; Vrugt et al. 2008).

More recent studies highlighted that groundwater recharge in systems with strong subsurface heterogeneities such as karst systems, exhibits a high sensitivity to changes in climatic forcings (Hartmann et al. 2017). In the specific case of prealpine karst catchments, these forcings controlling groundwater recharge are interception, evapotranspiration and snowmelt processes. Garrigues et al. (2015) and Sarrazin et al. (2018) showed that the sensitivity of groundwater recharge with respect to vegetation related processes, i.e. interception and evapotranspiration, mainly results from the spatial variability of soil properties. Moreover, Ollivier et al. (2021) underline that this sensitivity is further related to often missing information about spatially distributed and vegetation-dependent evapotranspiration dynamics. In cases where snowmelt represents a controlling factor in the water balance of karst areas, Doummar et al. (2018) showed that groundwater recharge estimations are most sensitive to temperature variations. That is mainly due to the importance temperature has for the timing of snow accumulation and melt and the resulting control on a spring's discharge behavior (Liu et al. 2021).

As it is difficult to measure interception, evapotranspiration and snowmelt, additional models are often applied to compute input time series for hydrologic models (Hartmann et al. 2014b; Mazzilli et al. 2012; Ollivier et al. 2020). Interception can be modeled using mechanistic (Gash et al. 1995; Liu 2001) and stochastic modeling approaches (Calder 1996; Hall 2003). Data demanding energy balance methods (Colaizzi et al. 2012; Penman 1948) or simple temperature-based parametrizations (Oudin et al. 2005; Thornthwaite 1948) provide evapotranspiration time series. Snow processes, which were recently shown to play a major role for groundwater recharge in pre-alpine and alpine areas (Jódar et al. 2020; Lucianetti et al. 2020), can be modeled using energy balance methods (Herrero et al. 2009; Marks et al. 1999) or simpler degree-day-factor methods (Girons Lopez et al. 2020; Martinec 1960). Reliable time series of interception, evapotranspiration and snowmelt are a prerequisite for a proper description of the water balance for distributed, semidistributed and conceptual models.

An example for a conceptual model applied to a pre-alpine karst system is the LuKARS model, which was developed by Bittner et al. (2018) for the Kerschbaum springshed in Austria. Given the natural characteristics of the springshed (forested catchment, elevation between 415 and $969 \mathrm{~m}$ asl, annual mean temperature of $8^{\circ} \mathrm{C}$ ), evapotranspiration, interception and snowmelt representations are expected to have an important influence on the modeled spring discharge (Bittner et al. 2018). However, since no direct measurements for these input data are available, simple algorithms have to be applied for computing the input time series for the LuKARS model (Bittner et al. 2020a).

While previous studies investigated the parametric uncertainties of LuKARS for the Kerschbaum springshed (Teixeira Parente et al. 2019), the presented article aims to investigate how much the input uncertainties affect model predictions. The hypotheses, which the authors want to test in this study, are, first, that the input uncertainties can vary seasonally, then, that it is possible to derive the specific importance of a single process, e.g. snowmelt, for groundwater recharge from its related uncertainties in the model output. This is of particular importance, as it serves as a practical example which is beneficial to guide researchers and decision-makers in favoring field experiments and data collection differently during different seasons to improve the output of a karst aquifer model. To study the uncertainty propagating to the spring discharge, three different modeling approaches are applied for each of the considered hydrological processes, i.e. interception, evapotranspiration and snow processes. In particular, the methods of DVWK (1996), Gash et al. (1995) and Liu (2001) are applied to compute interception, the methods of Hamon (1961), Oudin et al. (2005) and Thornthwaite (1948) to calculate evapotranspiration and the methods of Girons Lopez et al. (2020), Magnusson et al. (2014) and Martinec (1960) to model snowmelt and accumulation. The selection of lumped approaches is driven by data availability in the study area and in particular by the lack of radiation data. Then, all possible model combinations are run varying the parameters of the input models and by using the sampling algorithm of the Fourier Amplitude Sensitivity Test (FAST; Pianosi et al. 2015). Finally, the study investigates the impact of the input model parametrization on the LuKARS model output and how this changes over time. To conclude, the input uncertainties are compared with the parametric uncertainties, which were computed in an earlier study (Teixeira Parente et al. 2019).

\section{The study area}

The Kerschbaum springshed is located close to the city of Waidhofen a.d. Ybbs (Fig. 1a), about $100 \mathrm{~km}$ west of the city of Vienna (Austria; Fig. 1b). The study site covers an area of $2.5 \mathrm{~km}^{2}$. This pre-alpine recharge area forms part of the eastern foothills of the Northern Calcareous Alps and is dominated by a lithologic sequence of dolomitic basement rocks (Fig. 1c). The study area shows karst features such as springs, dry valleys and caves. Due to the absence of significant sinkholes, the groundwater recharge can be assumed barely influenced by pointinfiltration processes. Moreover, according to the study of 


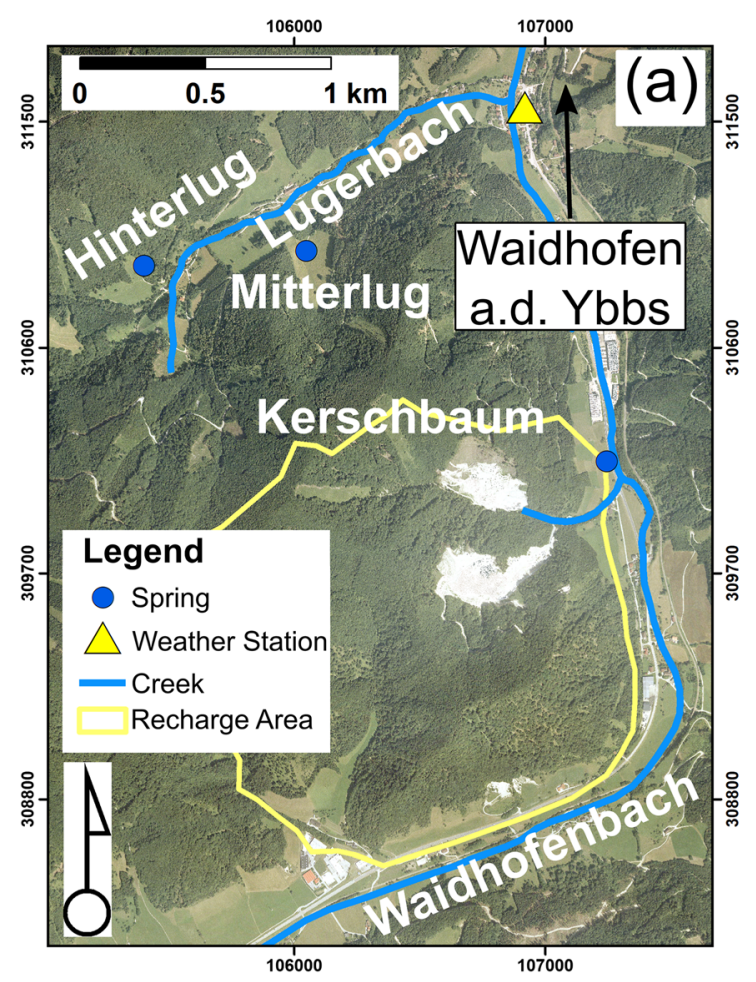

Fig. 1 Overview of the study area close to Waidhofen a.d. Ybbs and the LuKARS model implementation. a The orthophoto of the study area including the delineated recharge area of the Kerschbaum spring. b The

Narany et al. (2019), the Kerschbaum springshed is characterized by a deep karstified groundwater system with a wellconnected network of fractures and conduits.

The land cover is dominated by beech forests. Its spring provides a mean discharge of $34 \mathrm{~L} / \mathrm{s}$ to the regional water supply and shows a quick reaction time to precipitation and snowmelt events of 1 day (Bittner et al. 2021). Figure 2 shows the available precipitation, temperature, snow depth and discharge time series for the period from 1 January 2006 to 31 December 2007. These time series were measured at the weather station whose location is shown in Fig. 1a. For more information about the study area, the interested reader could refer to the publication of Narany et al. (2019).

\section{Methodology}

The paper briefly describes the lumped karst hydrological model LuKARS of the Kerschbaum springshed. For more information about the model the reader could refer to the publication of Bittner et al. (2020b). The paper then focuses on the description of both commonly applied and recently proposed parameterizations for interception, evapotranspiration and snow processes. Since precipitation and air temperature are the only meteorological parameters measured in the study area, temperature-based methods are used to compute evapotranspiration and snowmelt. Finally, the method used to

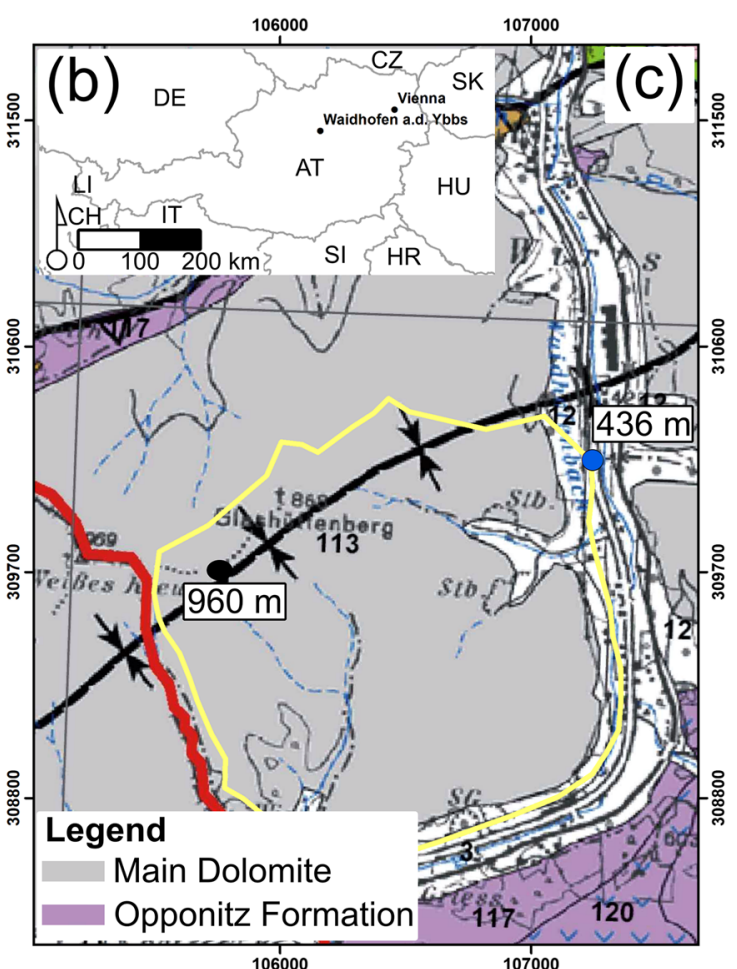

location of Waidhofen a.d. Ybbs seen from a European perspective. $\mathbf{c}$ The geological map of the study area (GBA 2021) including the elevations of the Kerschbaum spring and the summit of the Glashüttenberg

quantify the uncertainty of all investigated model combinations is described.

\section{The LuKARS model}

The LuKARS model is a lumped parameter model developed by Bittner et al. (2018) that considers the dominant hydrotopes in a recharge area as distinct response units. Hydrotopes are defined as landscape units with similar soil and land use characteristics (Arnold et al. 1998). Each hydrotope is characterized by a specific retention capacity. As Fig. 3a shows, shallow and coarse-textured soils lead to low soil storage and high quickflow intensity. In contrast, thick and fine-textured soils lead to high soil storage and low quick flow intensity. The conceptual model considers the hydrotopes to represent the vadose zone (soil-epikarst-infiltration zone) and to be directly connected to the saturated zone, which consists of a single linear storage recharged by each hydrotope independently. The duality of flow behavior is implemented by considering for each hydrotope both the fast flow component through the conduits and the slow diffusive discharge in the matrix. Each hydrotope simulates three different types of flow, i.e. the quickflow $\left(Q_{\text {hyd }}\right)$, the matrix infiltration $\left(Q_{\text {is }}\right)$ that feeds the baseflow storage $(B)$, and the secondary spring discharge ( $Q_{\text {sec }} ;$ Fig. 3b). $Q_{\text {hyd }}$ represents the discharge that is directly moved to the outlet of the catchment through preferential flow paths such as subsurface conduits, and factors that are 
Fig. 2 Data time series used in the presented study. a Daily precipitation $(\mathrm{mm})$, b daily snow depths (m), c daily air temperature $\left({ }^{\circ} \mathrm{C}\right)$ and $\mathbf{d}$ daily discharge of the Kerschbaum spring (L/s)
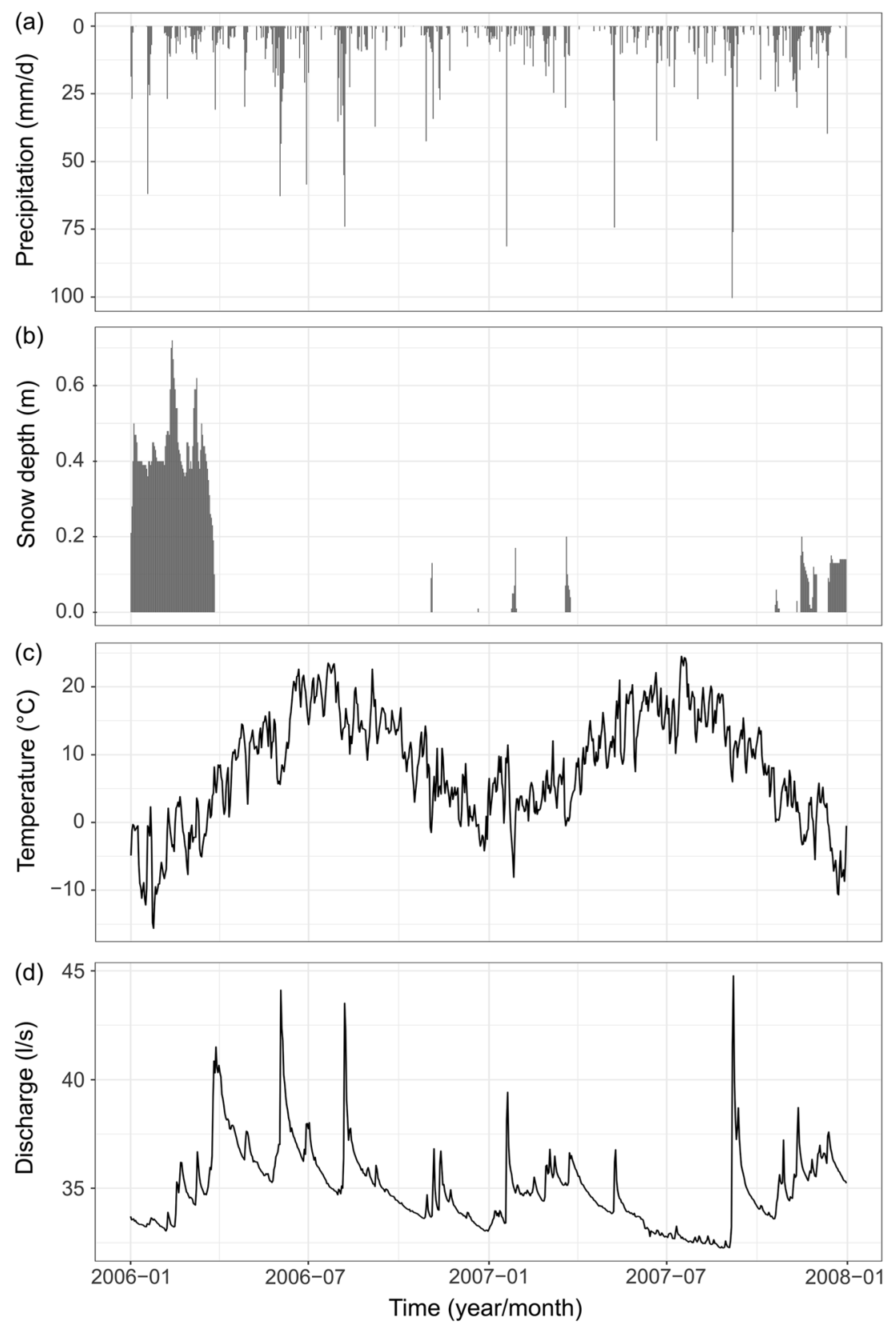

responsible for the fast reaction of the spring discharge to rainfall and snowmelt events. $Q_{\text {hyd }}$ is implemented considering the hysteretic behavior of the soil-epikarst system that starts after a constant hydrotope specific storage value $\left(E_{\max }\right)$ was exceeded and stops after a lower constant threshold $\left(E_{\min }\right)$ was reached. $Q_{\text {is }}$ is the water that infiltrates into the lower reservoir $B$ (Fig. 3) and, thus, represents the groundwater recharge. $Q_{\mathrm{sec}}$ is the flow that discharges outside the investigated recharge area and is activated only when the threshold for secondary spring discharge $\left(E_{\mathrm{sec}}\right)$ was exceeded. $Q_{\mathrm{is}}, Q_{\mathrm{sec}}$ and $Q_{\mathrm{b}}$ (the baseflow) are implemented using linear transfer functions. Finally, $Q_{\text {tot }}$ is the discharge at the spring. The mathematical equations and a graphical user interface for the model are provided in Bittner et al. (2018) and (2020a), respectively.

\section{Interception}

The approach applied by Bittner et al. (2018) was based on the percentages for interception of beech forest stands proposed by DVWK (1996). This study further considers the methods proposed by Gash et al. (1995) and Liu (2001).

DVWK (1996) suggests that $11 \%$ of precipitation is intercepted from beeches in the winter season (21 December, $d_{\mathrm{w}}$ ), whereas $17 \%$ of precipitation is intercepted in the summer season (21 June, $d_{\mathrm{s}}$ ). A linear interpolation is applied between these values following Eqs. (1) and (2), which compute daily time series of interception $I(\mathrm{~mm} /$ day) for the time between 21 December and 21 June and the time 
Fig. 3 The conceptual modeling approach of LuKARS. a

Conceptual representation of the four implemented hydrotopes. Hyd 1 indicates the dolomite quarries with no groundwater recharge and the dominance of surface runoff (SF). Hyd 2 and Hyd 4 represent coarse-textured and fine-textured soils, respectively. b The bucket-type model implementation of dominant hydrotopes. $Q_{\text {sec }}$ is the secondary spring discharge, $Q_{\mathrm{hyd}}$ the quickflow, $Q_{\text {is }}$ the matrix infiltration feeding the baseflow storage B, $Q_{\mathrm{b}}$ the baseflow and $Q_{\text {tot }}$ the discharge at the spring. $E_{\mathrm{sec}}, E_{\max }$ and $E_{\min }$ are thresholds storage values regulating the activation of the discharge components
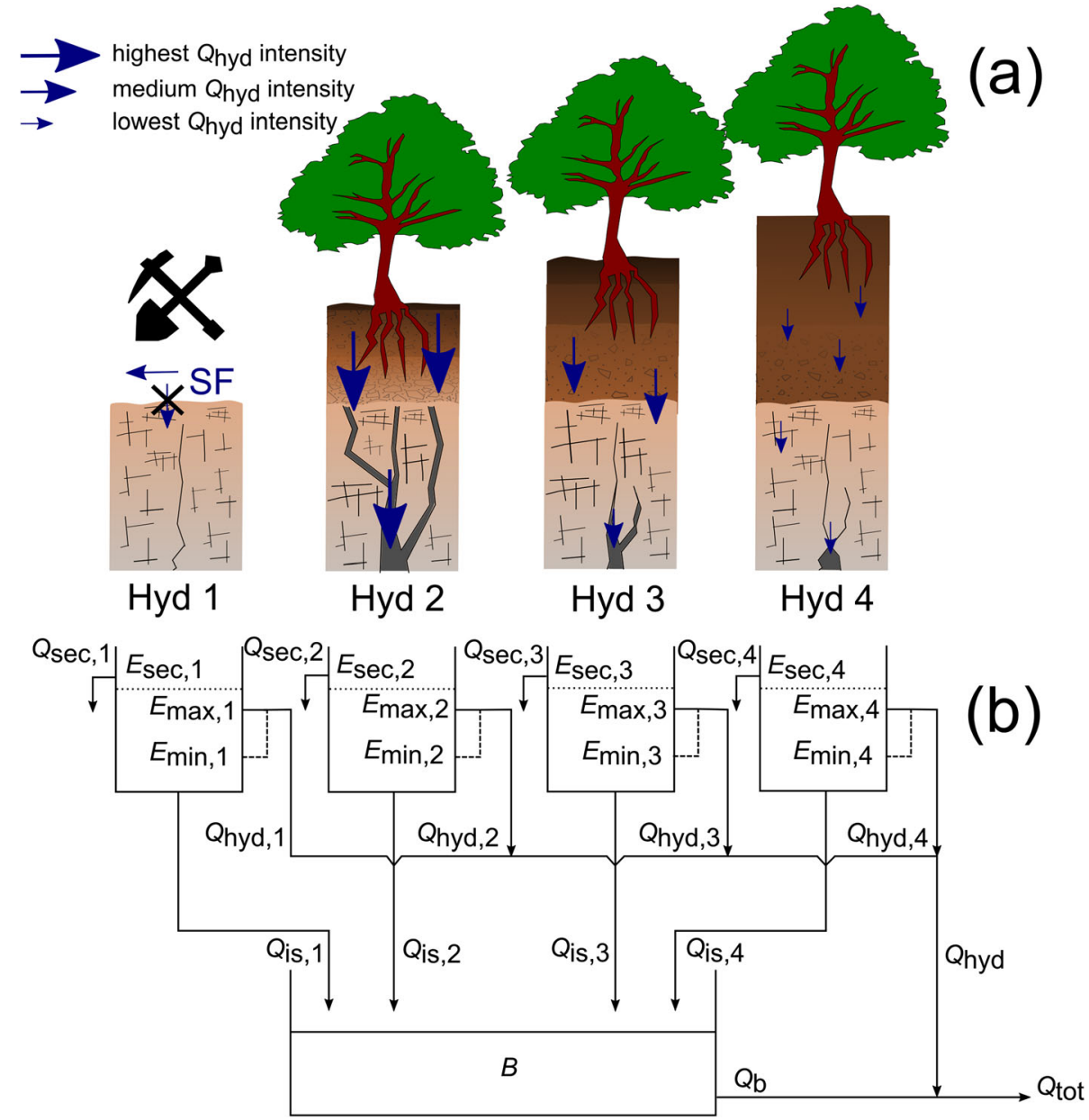

between 21 June and 21 December, respectively. The maximum interception is limited to $5 \mathrm{~mm} /$ day.

$$
\text { if } \begin{aligned}
I & <5 \frac{\mathrm{mm}}{\text { day }}, I=11+\left(\frac{17-11}{d_{\mathrm{s}}-d_{\mathrm{w}}}\right)\left(d-d_{\mathrm{w}}\right), \text { then } I \\
& =5 \frac{\mathrm{mm}}{\text { day }} \text { from Dec } 21 \text { to June } 21
\end{aligned}
$$

if $I<5 \mathrm{~mm} /$ day, $I=17+\left(\frac{11-17}{d_{\mathrm{w}}-d_{\mathrm{s}}}\right)\left(d-d_{\mathrm{s}}\right)$, then $I$

$$
=5 \mathrm{~mm} / \text { day from June } 21 \text { to Dec } 21
$$

The approach by Gash et al. (1995) is based on the calculation of a gross rainfall that is needed to saturate the canopy, i.e. $P_{\mathrm{g}}^{\prime}(\mathrm{mm}) . P_{\mathrm{g}}^{\prime}$ is calculated using Eq. (3).

$P_{\mathrm{g}}^{\prime}=-\left[\frac{C_{\mathrm{m}}}{\operatorname{ER}(1-p)}\right] \ln (1-\mathrm{ER})$

where $C_{\mathrm{m}}$ is the stand storage capacity ( $\mathrm{mm}$ ), ER (-) is the ratio between the mean evaporative rate $E$ and the mean rainfall rate of the event for saturated canopy conditions $R$. The parameter $p$ represents the free throughfall coefficient (-). For a daily time step, if the precipitation $P(\mathrm{~mm} /$ day) is larger than $P_{\mathrm{g}}^{\prime}(\mathrm{mm} / \mathrm{day}), I(\mathrm{~mm} /$ day) can be calculated with Eq. (4).

$$
I=(1-p) P_{\mathrm{g}}^{\prime}+(1-p) \mathrm{ER}\left(P-P_{\mathrm{g}}^{\prime}\right)
$$

If $P<P_{\mathrm{g}}^{\prime}, I$ is computed following Eq. (5).

$I=(1-p) P$

The method proposed by Liu (2001) requires the definition of the same parameters as in the method of Gash et al. (1995). However, instead of differentiating between the cases in which precipitation $P$ is greater or smaller than the gross rainfall that is needed to saturate the canopy $\left(P_{\mathrm{g}}^{\prime}\right)$, the exponential function in Eq. (6) is defined to compute daily interception amounts $(I)$.

$I=C_{\mathrm{m}}\left[1-e^{\left(-\frac{(1-p)}{C_{\mathrm{m}}} P\right)}\right]\left[1-\frac{\mathrm{ER}}{(1-p)}\right]+\mathrm{ER} \cdot P$

Liu (2001) investigated the parameter sensitivities of Eqs. (4) and (6) and showed that an overestimation of either $C_{\mathrm{m}}$ or ER results in an overestimation of interception, whereas large 
values of $p$ cause an underestimation of interception. Moreover, the parameter sensitivities depend on the magnitude of a considered rainfall event and the type of canopy. For example, ER is most sensitive in areas dominated by intense rainfall events, whereas ER and $C_{\mathrm{m}}$ are most sensitive in areas characterized by small rainfall events. The parameter $p$ is sensitive when the models are applied to areas with small rainfall events and open canopies.

\section{Evapotranspiration}

The Thornthwaite (1948) evapotranspiration model was used to calculate the potential evapotranspiration $\left(\mathrm{ET}_{\mathrm{pot}}\right)$ in the original LuKARS model of the Kerschbaum spring (Bittner et al. (2018). In this work, the simulation approaches proposed by Hamon (1961) and Oudin et al. (2005) are additionally applied. It is important to note that Bittner et al. (2018) and

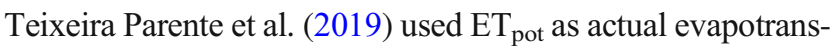
piration $\left(\mathrm{ET}_{\mathrm{act}}\right)$, since the results obtained for the annual $\mathrm{ET}_{\text {pot }}$ losses were in good agreement with $\mathrm{ET}_{\text {act }}$ computed in previous studies for the same study area (Markart et al. 2006). Specifically, for the years 2006-2007, Bittner et al. (2018) calculated a total of $45 \% \mathrm{ET}_{\text {pot }}$, which is in good agreement with the $43 \% \mathrm{ET}_{\text {act }}$ presented in Markart et al. (2006). In the presented study, $\mathrm{ET}_{\text {act }}$ is hence considered to be equal to the $\mathrm{ET}_{\text {pot }}$ to be able to compare the different model configurations under the same conditions.

Thornthwaite (1948) provides estimates for monthly $\mathrm{ET}_{\text {pot }}$ and assumes that once the mean monthly temperature becomes larger than $0{ }^{\circ} \mathrm{C}, \mathrm{ET}_{\text {pot }}$ becomes 0 . In this method, the hours of daylight are assumed to be 12 and each month is 30 days long. Then, $\mathrm{ET}_{\text {pot }}(\mathrm{mm} / \mathrm{month})$ is calculated as shown in Eq. (7),

$\mathrm{ET}_{\text {pot }}=k_{\mathrm{TH}}\left(10 \frac{T_{\text {Mean }}}{H}\right)^{r}$

where $k_{\mathrm{TH}}\left(\mathrm{mm} /\right.$ month) is a proportionality constant, $T_{\text {mean }}$ $\left({ }^{\circ} \mathrm{C}\right)$ the mean monthly temperature and $H\left({ }^{\circ} \mathrm{C}\right)$ is the heat index defined in Eq. (8),

$H=\left(\frac{T_{\text {Mean }}}{5}\right)^{1.514}$

with $r$ an exponent given by Eq. (9).

$r=6.75 e^{-7} H^{3}+7.71 e^{-5} H^{2}+1.792 e^{-2} H+0.49239(9)$

As proposed by Bittner et al. (2018), the monthly $\mathrm{ET}_{\text {pot }}$ are divided by the number of days and the resulting daily $\mathrm{ET}_{\text {pot }}$ are to be representative for the 15 th day of a month. In order to obtain daily $\mathrm{ET}_{\text {pot }}(\mathrm{mm} /$ day) from this method, a linear interpolation is applied between these representative $\mathrm{ET}_{\text {pot }}$ values.
Oudin et al. (2005) derived an empirical equation to estimate daily $\mathrm{ET}_{\text {pot }}(\mathrm{mm} /$ day) as input for lumped rainfall-runoff models. They tested various $\mathrm{ET}_{\mathrm{pot}}$ modeling approaches for numerous catchments in France, Australia and the United States. Their goal was to identify those atmospheric variables which provide the best streamflow predictions when being used as input for $\mathrm{ET}_{\text {pot }}$ models. The equation they derived is shown in Eq. (10),

$\mathrm{ET}_{\text {pot }}=\left[\begin{array}{ll}0.408 & H_{\mathrm{O}}\end{array}\right]\left[k_{\mathrm{OU}}\left(T_{\text {Mean }}+5\right)\right]$

where $H_{\mathrm{O}}$ is the extraterrestrial solar radiation $\left[\mathrm{MJ} /\left(\mathrm{m}^{2} /\right.\right.$ day $\left.)\right]$, $k_{\mathrm{OU}}\left[\mathrm{m}^{3} / \mathrm{kg} /\left(1,000 \mathrm{MJ}^{2}{ }^{\circ} \mathrm{C}\right)\right]$ is a proportionality constant, $T_{\text {mean }}$ is the mean daily temp $\left({ }^{\circ} \mathrm{C}\right)$, and 0.408 is an approximation for the latent heat flux $(\mathrm{MJ} / \mathrm{kg})$. It is important to note that $\mathrm{ET}_{\text {pot }}$ is $0(\mathrm{~mm} /$ day $)$ if $T_{\text {mean }} \leq 5\left({ }^{\circ} \mathrm{C}\right)$.

The third method applied to calculate $\mathrm{ET}_{\text {pot }}$ was proposed by Hamon (1961), who derived a simple procedure to be used in water balance estimations. The goal was to use readily available data, i.e. daily air temperature $\left(T_{\text {mean }}\right)$, for $\mathrm{ET}_{\text {pot }}$ estimations. The derived methodology is based on the saturated water vapor concentration at $T_{\text {mean }}$, i.e. $e^{0}\left(T_{\text {mean }}\right)(\mathrm{kPa})$ and is expressed by Eq. (11),

$\mathrm{ET}_{\text {pot }}=k_{\mathrm{HA}} \frac{N}{12}\left[216.7 e^{0}\left(T_{\text {mean }}\right) /\left(T_{\text {mean }}+273.3\right)\right]$

where $k_{\mathrm{HA}}(\mathrm{mm} /$ day) is a proportionality constant and $N$ is the maximum number of daylight hours. $e^{0}\left(T_{\text {mean }}\right)$ was approximated using the modified Magnus equation proposed by Alduchov and Eskridge (1996) that is shown in Eq. (12).

$e^{0}\left(T_{\text {mean }}\right)=6.1094 e^{17.625 T_{\text {man }} /\left(243.04+T_{\text {man }}\right)}$

\section{Snowmelt}

Bittner et al. (2018) used the method proposed by Martinec (1960) to model snowmelt and storage for the Kerschbaum spring recharge area. This study additionally considers the methods described by Girons Lopez et al. (2020) and Magnusson et al. (2014). All snow routines considered in this framework assume that the energy available for snowmelt is proportional to air temperature. This means that below a certain threshold temperature $T_{\mathrm{T}}$, precipitation falls as snow, whereas rainfall occurs for temperatures above this threshold. The proportionality of snowmelt $(M)$ is controlled by the degree-day factor $C_{0}\left[\mathrm{~mm} /\left(\right.\right.$ day $\left.\left.{ }^{\circ} \mathrm{C}\right)\right]$ and the daily mean temperature $T_{\text {mean }}\left({ }^{\circ} \mathrm{C}\right)$. Moreover, all the considered snow models neglect sublimation processes, which is often the case in degree-day methods.

The degree-day method proposed by Martinec (1960) simulates $M(\mathrm{~mm} /$ day) using Eq. (13). 
$M=C_{0} \max \left(0, T_{\text {mean }}-T_{\mathrm{T}}\right)$

While Martinec (1960) considers $C_{0}$ to be constant, Braun and Renner (1992) argue that this factor should be changing over time, since environmental conditions, e.g. solar inclination and snow albedo, vary seasonally. Girons Lopez et al. (2020) describe a seasonally varying degree-day factor, i.e. $C_{0, n}$, based on a sine function. The intensity by which $C_{0}$ varies is controlled by an amplitude factor $C_{0, \mathrm{a}}\left[\mathrm{mm} /\left(\right.\right.$ day $\left.\left.{ }^{\circ} \mathrm{C}\right)\right]$. Then, $C_{0, n}$ is computed as shown in Eq. (14), where $n$ is the time (day).

$C_{0, n}=C_{0}+\frac{1}{2} C_{0, \mathrm{a}} \sin \frac{2 \pi(n-81)}{365}$

Finally, Magnusson et al. (2014) approach the calculation of snowmelt with the exponential function shown in Eq. (15),

$M=C_{0} M_{\mathrm{M}}\left[\frac{T_{\text {mean }}-T_{\mathrm{T}}}{M_{\mathrm{M}}}+\ln \left(1+e^{-\frac{T_{\text {mean }}-T_{\mathrm{T}}}{M_{\mathrm{M}}}}\right)\right]$

where $M_{\mathrm{M}}$ represents a snowmelt transition $\left({ }^{\circ} \mathrm{C}\right)$. This method allows for melting to occur even below freezing temperature.

According to the investigation of Girons Lopez et al. (2020), who tested a variety of modifications to different temperature-based snow routines, the most sensitive parameters in the models applied in this study are the snowmelt transition $M_{\mathrm{M}}$ and the temporally varying degree-day factor $C_{0, n}$.

\section{Parameter sampling and investigated model combinations}

Appropriate parameter ranges are defined for all unknown parameters in the equations describing interception, evapotranspiration and snowmelt. The parameter ranges selected for the nine considered calibration parameters, i.e. $C_{\mathrm{m}}, p$, ER, $k_{\mathrm{OU}}, k_{\mathrm{HA}}, C_{0}, T_{\mathrm{T}}, C_{0}$, a and $M_{\mathrm{M}}$, are shown in Table 1. The specific range of values for each parameter is based on previous studies, which are indicated in Table 1.

This study considers the model configuration from Bittner et al. (2018) as the reference model, whose results are used to evaluate the performance of all the considered model combinations. All investigated model combinations are shown in Table 2. The name given to each model combination indicates the input algorithms which have been changed from Bittner et al. (2018). Each simulation is run with daily time steps for a warm-up period between 2001 and 2005 and an evaluation period from 2006 to 2007 . The selection of these two particular years was driven, firstly, by the fact that the original LuKARS model from Bittner et al. (2018) was calibrated and validated for the years 2006 and 2007, respectively. Secondly, the relevant contrast in snow accumulation and evaporative demand between 2006 and 2007 makes it possible to account for the climatic variability between different years. Indeed, as Fig. 2b shows, the winter in 2006 is characterized by snow depth values up to $0.72 \mathrm{~m}$, whereas almost no snow accumulation occurred in 2007 ( $\max$ snow depth $=0.2 \mathrm{~m}$ ).

The sampling algorithm of the Fourier Amplitude Sensitivity Test (FAST), which was developed by Cukier et al. (1978) and implemented in the SAFE toolbox (Pianosi et al. 2015), is used in this study to obtain for each model combination a set of values that covers the full parameter space of each parameter. To avoid unrealistic water budgets, the model input time series computed with each parameter sample of each model combination are compared with the computed input time series of Bittner et al. (2018) for the hydrological year 2006. All parameter samples leading to an annual model input that differs more than $15 \%$ from the water volume computed by Bittner et al. (2018) are discarded. Then, the remaining 2,673 parameter samples are used to investigate all possible model combinations, i.e. 26 , which are evaluated and compared with the results of Bittner et al. (2018) for the period 2006 and 2007. For the input algorithms of the original Kerschbaum spring LuKARS model, i.e. DVWK (1996), Thornthwaite (1948) and Martinec (1960), rather than defining parameter ranges and samples, this study keeps the parameters fixed and equal to those found in Bittner et al. (2018) (Table 1). The model combinations including the total number of investigated samples are summarized in Table 2. For the sake of completeness, Appendix shows the calibrated LuKARS model parameters found in Bittner et al. (2018). The hydrotope specific parameters control the behavior of the soilepikarst system, of the matrix infiltration and of the quickflow through the conduits, while the baseflow storage parameters determine the response of the saturated zone.

\section{Results}

The results of this study are presented in the following sections. First, the uncertainties of single processes in relation to the parametric uncertainties of the Kerschbaum spring LuKARS model which were computed in an earlier study (Teixeira Parente et al. 2019). Notice that this comparison is mainly qualitative, since the parameter uncertainty was estimated using only the combination DVWK - Thornthwaite Martinec with fixed input parameters. Then, section 'Evaluation of all model combinations' focuses on the comparison of the results of all evaluated model combinations and highlights how the input uncertainties change when considering more processes to be unknown, i.e. interception, evapotranspiration and snowmelt. The analyses focus on the comparison of the interquartile range of the LuKARS model outputs as an indicator for model uncertainty. Moreover, the interquartile ranges are normalized with the observed spring 
Table 1 Overview of the calibration parameter used in the presented methodology, including their respective parameter range, their description and the reference. The parameters marked with ${ }^{(*)}$ are taken fixed and correspond to the input algorithms used in Bittner et al. (2018)

Table 2 Overview of the 26 investigated model combinations including the total number of investigated parameter samples

\begin{tabular}{|c|c|c|c|}
\hline Parameter & $\begin{array}{l}\text { Parameter } \\
\text { range }\end{array}$ & Description & Reference \\
\hline$C_{\mathrm{m}}$ & $0.1-5$ & Stand storage capacity (mm) & Liu (2001) \\
\hline$p$ & $0.01-0.6$ & Free throughfall coefficient (-) & Liu (2001) \\
\hline ER & $0.01-0.4$ & $\begin{array}{l}\text { Ratio between mean evaporative rate and mean } \\
\text { rainfall } \\
\text { rate for saturated canopy conditions }(-)\end{array}$ & Liu (2001) \\
\hline$k_{\mathrm{OU}}$ & $0.006-0.012$ & $\begin{array}{l}\text { Proportionality constant in Oudin's method } \\
\qquad\left[\mathrm{m}^{3} \mathrm{~kg} /\left(1,000 \mathrm{MJ}^{2}{ }^{\circ} \mathrm{C}\right)\right]\end{array}$ & Almorox et al. (2015) \\
\hline$k_{\mathrm{HA}}$ & $0.1-0.2$ & $\begin{array}{l}\text { Proportionality constant in Hamon's method } \\
(\mathrm{mm} / \text { day })\end{array}$ & Almorox et al. (2015) \\
\hline$C_{0}$ & $1-10$ & Degree-day factor $\left[\mathrm{mm} /\left(\right.\right.$ day $\left.\left.{ }^{\circ} \mathrm{C}\right)\right]$ & Bittner et al. (2018) \\
\hline$T_{\mathrm{T}}$ & $-2-2$ & Threshold temperature $\left({ }^{\circ} \mathrm{C}\right)$ & Bittner et al. (2018) \\
\hline$C_{0, \mathrm{a}}$ & $1-10$ & Amplitude factor $\left[\mathrm{mm} /\left(\right.\right.$ day $\left.\left.{ }^{\circ} \mathrm{C}\right)\right]$ & Hottelet et al. (1994) \\
\hline$M_{\mathrm{M}}$ & $1-10$ & Snowmelt transition $\left({ }^{\circ} \mathrm{C}\right)$ & $\begin{array}{l}\text { Magnusson et al. } \\
\text { (2014) }\end{array}$ \\
\hline$k_{\mathrm{TH}}{ }^{(*)}$ & 16 & $\begin{array}{l}\text { Proportionality constant in Thornthwaite's } \\
\text { method (-) }\end{array}$ & Bittner et al. (2018) \\
\hline$C_{0}{ }^{(*)}$ & 4 & Degree-day factor $\left[\mathrm{mm} /\left(\right.\right.$ day $\left.\left.^{\circ} \mathrm{C}\right)\right]$ & Bittner et al. (2018) \\
\hline$T_{\mathrm{T}}^{(*)}$ & 0.5 & Threshold temperature $\left({ }^{\circ} \mathrm{C}\right)$ & Bittner et al. (2018) \\
\hline
\end{tabular}

\begin{tabular}{|c|c|c|c|c|}
\hline Name of model combination & Samples & I model & ET model & M model \\
\hline Gash & 17 & Gash & Thornthwaite & Martinec \\
\hline Liu & 11 & Liu & Thornthwaite & Martinec \\
\hline Oudin & 24 & DVWK & Oudin & Martinec \\
\hline Hamon & 19 & DVWK & Hamon & Martinec \\
\hline Girons Lopez & 105 & DVWK & Thornthwaite & Girons Lopez \\
\hline Magnusson & 105 & DVWK & Thornthwaite & Magnusson \\
\hline Gash - Hamon & 48 & Gash & Hamon & Martinec \\
\hline Gash - Girons Lopez & 63 & Gash & Thornthwaite & Girons Lopez \\
\hline Gash - Magnusson & 64 & Gash & Thornthwaite & Magnusson \\
\hline Gash - Oudin & 59 & Gash & Oudin & Martinec \\
\hline Liu - Hamon & 34 & Liu & Hamon & Martinec \\
\hline Liu - Girons Lopez & 51 & Liu & Thornthwaite & Girons Lopez \\
\hline Liu - Magnusson & 52 & Liu & Thornthwaite & Magnusson \\
\hline Liu - Oudin & 45 & Liu & Oudin & Martinec \\
\hline Girons Lopez - Hamon & 232 & DVWK & Hamon & Girons Lopez \\
\hline Girons Lopez - Oudin & 281 & DVWK & Oudin & Girons Lopez \\
\hline Magnusson - Hamon & 238 & DVWK & Hamon & Magnusson \\
\hline Magnusson - Oudin & 285 & DVWK & Oudin & Magnusson \\
\hline Gash - Girons Lopez - Hamon & 114 & Gash & Hamon & Girons Lopez \\
\hline Gash - Girons Lopez - Oudin & 153 & Gash & Oudin & Girons Lopez \\
\hline Gash - Magnusson - Hamon & 113 & Gash & Hamon & Magnusson \\
\hline Gash - Magnusson - Oudin & 150 & Gash & Oudin & Magnusson \\
\hline Liu - Girons Lopez - Hamon & 84 & Liu & Hamon & Girons Lopez \\
\hline Liu - Girons Lopez - Oudin & 121 & Liu & Oudin & Girons Lopez \\
\hline Liu - Magnusson - Hamon & 83 & Liu & Hamon & Magnusson \\
\hline Liu - Magnusson - Oudin & 122 & Liu & Oudin & Magnusson \\
\hline
\end{tabular}


discharge to make the interpretation of input uncertainties independent of high and low flow periods, occurring during snowmelt and snow accumulation periods, respectively.

Figure 4 shows the cumulative input values generated with all parameter samples for each applied algorithm. As the analyses focus on the interquartile range of model outputs, also the generated cumulative recharge values of that range are shown. Cumulated sums allow a better visualization through continuous plots. It is observed that the inputs computed with the
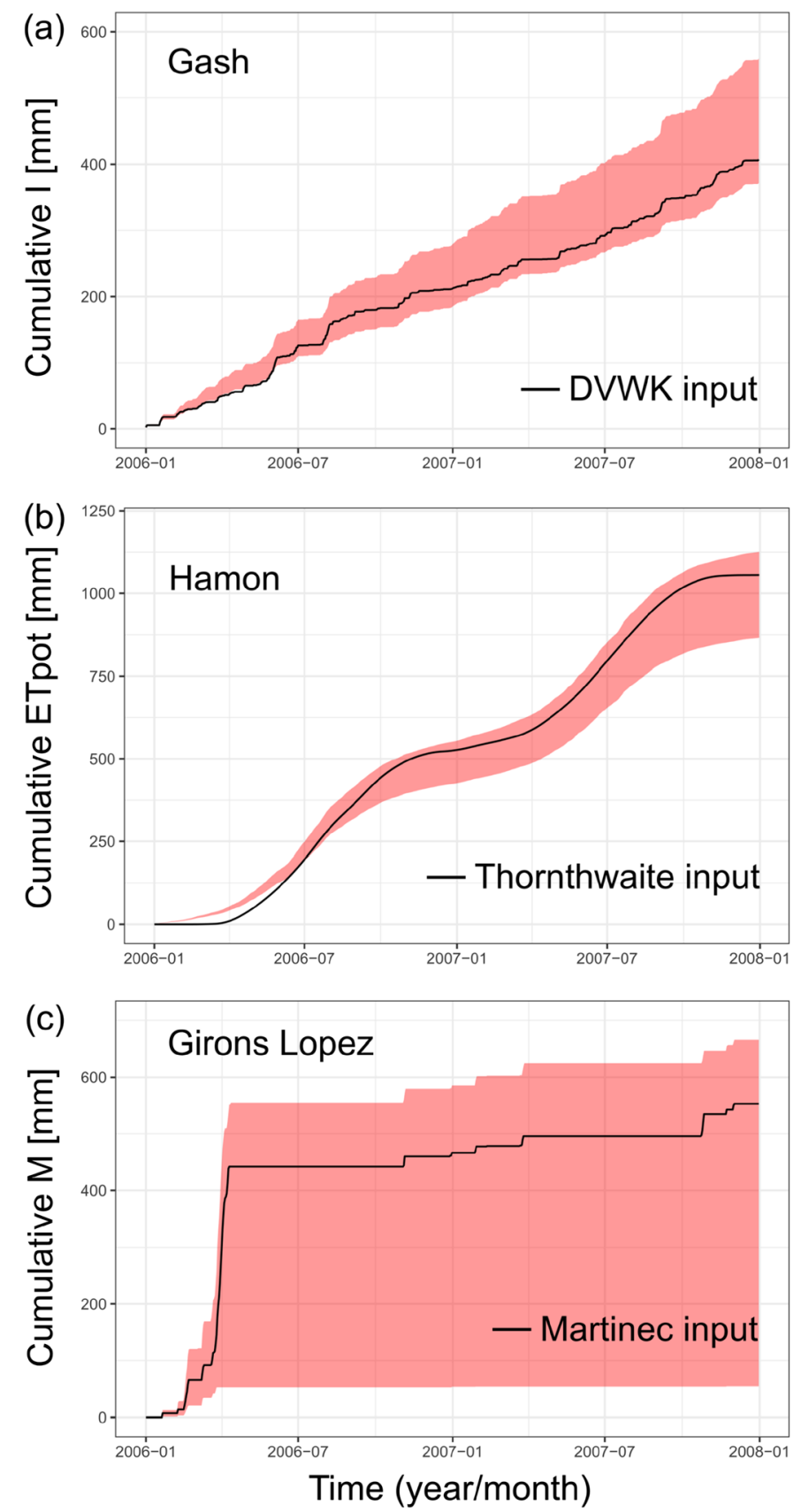

Fig. 4 The plots show the interquartile range of the cumulative input values for each applied algorithm. For comparison, the black lines highlight the inputs used in the study of Bittner et al. (2018). a The different algorithms are well distributed around the input time series used in the original Kerschbaum spring LuKARS model. Slight deviations are only visible for $\mathrm{ET}_{\text {pot }}$ in 2006, where the method of Hamon (1961) partially overshoots the inputs generated with the method of Thornthwaite (1948), and in 2007, where the Thornthwaite (1948) method overshoots the interquartile range of inputs computed with the method of Oudin et al. (2005). These deviations are related to the linear interpolation which is applied to derive daily values from the
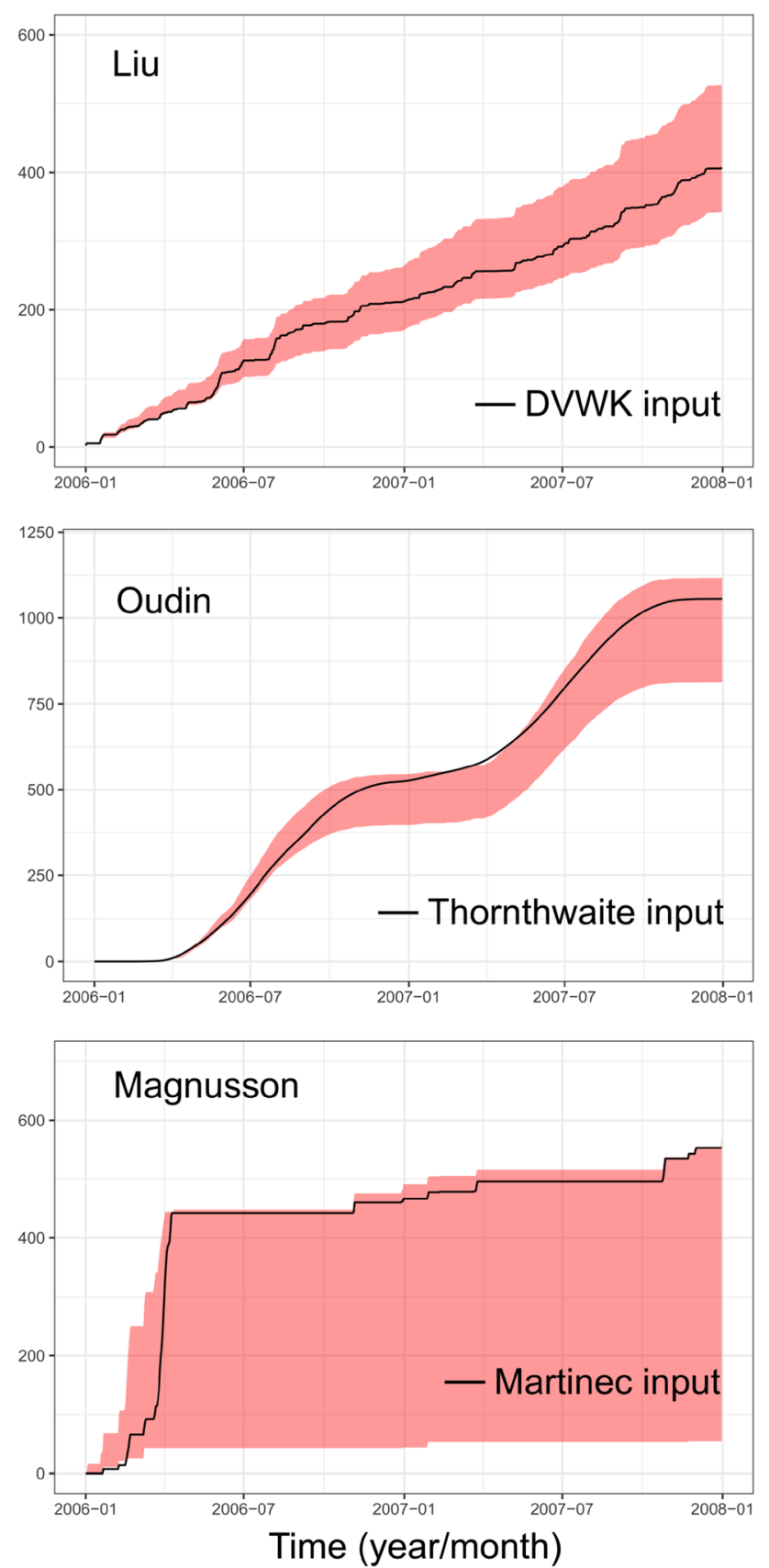

interception inputs, $\mathbf{b}$ the potential evapotranspiration inputs and $\mathbf{c}$ the potential snowmelt inputs 
monthly $\mathrm{ET}_{\text {pot }}$, obtained with the methodology of Thornthwaite (1948).

\section{Model input uncertainties related to single hydrological processes}

In this section, the focus is on the uncertainties related to single hydrological processes, i.e. interception, evapotranspiration and snowmelt, how these uncertainties change in different periods of the year and how they compare to the parametric uncertainties previously computed by Teixeira Parente et al. (2019). The model parameters, which were considered in the evaluation of the parametric uncertainties of the LuKARS model, are highlighted with an asterisk (*) in the Appendix and are the discharge coefficients and exponents, minimum and maximum storage capacities, and activation level of secondary spring discharge for hydrotopes Hyd 2, Hyd 3 and Hyd 4 (Teixeira Parente et al. 2019).

Figure 5 shows that the interquartile ranges resulting from uncertainties in interception (model combinations Gash and Liu) are generally smaller than the evapotranspiration and parametric uncertainties. Moreover, the uncertainties related to interception do not show a distinct seasonal variation in 2006; however, a slight seasonal variation with increasing interception over the summer period can be observed in 2007. Moreover, both Gash and Liu model follow the same temporal dynamics and lead to very similar interquartile ranges, showing that the choice of the interception model is not very significant for this case study.

Regarding the interquartile ranges resulting from the use of the Oudin et al. (2005) and Hamon (1961) methods, it is noted that the uncertainties related to evapotranspiration are characterized by a clear seasonal variability. The method of Oudin et al. (2005) brings the largest difference in the normalized interquartile range, which increases over the summer seasons in 2006 from 0.03 (29 March) to 0.06 (2 August) and in 2007 from below 0.04 (21 January) to 0.1 ( 5 September) and decreases again in the winter seasons. Overall, the normalized interquartile range of evapotranspiration is smaller than the parametric uncertainties. Moreover, most of the time the uncertainties of evapotranspiration are higher than the snowmelt uncertainties, even over the winter period 2006-2007. The uncertainties in snowmelt are higher than the evapotranspiration uncertainties for an extended period only in the early year 2006. Also in this case, as it was observed for interception, the difference in the normalized interquartile range between the Hamon and the Oudin models is rather small, reaching a maximum value of 0.04 on 4 September 2007.

Figure 5 also shows that the uncertainties in snowmelt have the highest temporal variability of all investigated hydrological processes. Here, the method of Magnusson et al. (2014) bears the largest variation in normalized interquartile range, i.e. between 0.18 on 19 January 2006, and 0.003 on 6 November 2006. Moreover, similar to the normalized interquartile ranges of model results considering uncertainties in evapotranspiration, the results show a seasonal dependence of uncertainties in snowmelt. The normalized interquartile range of LuKARS results considering snowmelt to be uncertain exceeds all other normalized interquartile ranges in January 2006. In contrast, the snow-melt-related uncertainties are even smaller than the uncertainties related to interception during the winter season 2006-2007. Moreover, the normalized interquartile range of LuKARS results considering snowmelt to be uncertain almost becomes $0(<2 \%$ of the measured discharge) in summertime in 2006 and 2007.

In case of snow processes, the choice of the model appears to be more relevant than for evapotranspiration and

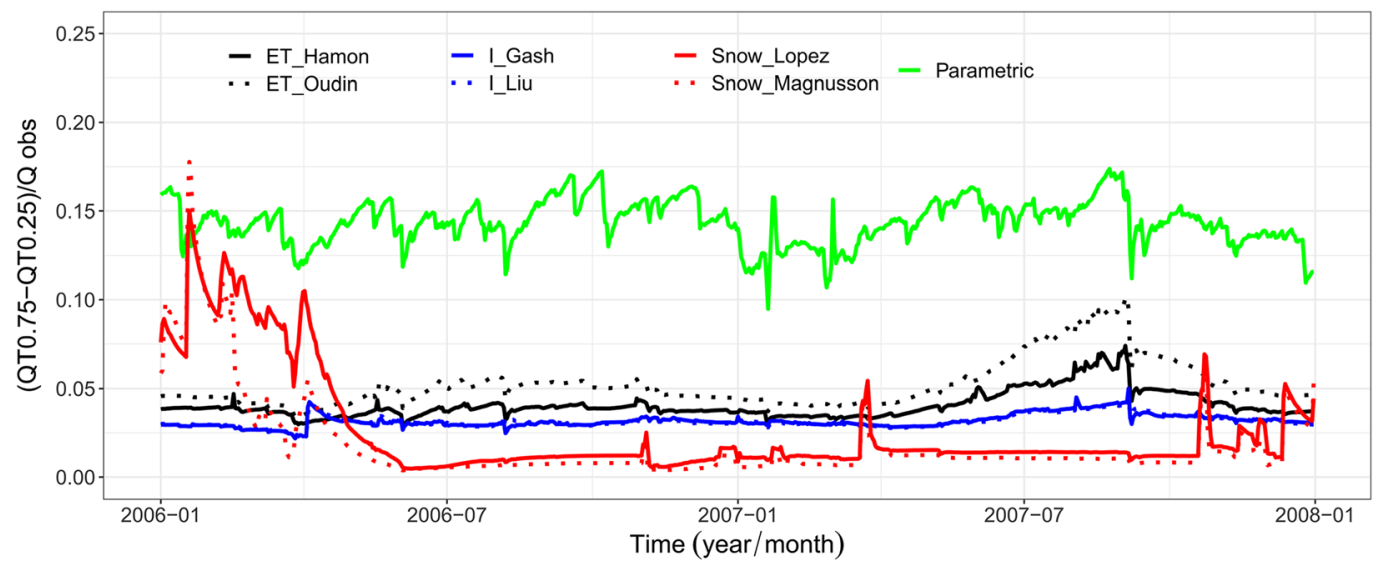

Fig. 5 Interquartile ranges of LuKARS model outputs normalized by the observed discharge. Single processes, i.e. interception, evapotranspiration and snowmelt, are considered as uncertain. For comparison, the parametric uncertainties of the Kerschbaum LuKARS model computed by Teixeira Parente et al. (2019) are also shown. A clear seasonal dependence of uncertainties related to snowmelt and evapotranspiration can be identified 
interception. On the one hand, the mean of the differences in the normalized interquartile range between both ET models, i.e. 0.011 , is higher than the mean of the normalized interquartile range differences between the snow models, i.e. 0.008. On the other hand, the maximum difference in the normalized interquartile range is identified between the Girons Lopez and Magnusson models, i.e. is 0.06 on 21 March 2006. This is reasonable, since snow processes do not play a role over the whole time of a year, whereas ET does.

\section{Evaluation of all model combinations}

The minimum and maximum percentage discrepancies between the simulated and observed spring discharge for each model combination are shown in Fig. 6. Figure 7 shows the interquartile ranges of all model evaluations, including the results of the parametric uncertainty study performed in Teixeira Parente et al. (2019) and the simulated spring discharge obtained from the original Kerschbaum LuKARS model. Comparing the interquartile ranges of the different model combinations (Fig. 7), it is seen that including more uncertain hydrological processes does not necessarily lead to an increase in the output variance. As an example, Fig. 8a,b shows two different cases, characterized by an increase and a decrease in output variance with increasing process complexity, respectively. Figure 8a compares the model combinations Liu, Liu-Magnusson and Liu-Magnusson-Oudin, therefore introducing progressive uncertainties in interception, snowmelt and evapotranspiration. Here, the normalized interquartile ranges increase with the number of hydrological inputs considered as uncertain. Figure $8 \mathrm{~b}$ considers the model combinations Magnusson, Magnusson-Oudin and GashMagnusson-Oudin. In contrast to the previous case, the model combination considering snow and evapotranspiration as uncertain input (Magnusson-Oudin) shows larger output variability than the model considering uncertainties in all the three processes (Gash-Magnusson-Oudin). Looking at all model combinations in Fig. 7, the highest normalized interquartile ranges are noted for model combinations considering snowmelt and evapotranspiration to be uncertain.

\section{Discussion}

When considering the uncertainties related to single processes, no significant seasonal variation is observed in the normalized interquartile range related to uncertainties in interception. In the particular case of a broadleaf forest, in Waidhofen a.d. Ybbs beech forest, a more pronounced seasonal variation should be expected due to the higher interception capacity of the leafs in the summer period. This change in canopy cover is, however, not considered in the modeling approaches of Gash et al. (1995) and Liu (2001). In order to obtain more realistic interception estimates, future works should represent variable canopy cover by considering the gross rainfall needed to saturate the canopy, i.e. $P_{\mathrm{g}}^{\prime}$, to be changing over time rather than constant. This could be achieved by a temporally varying stand storage capacity $\left(C_{\mathrm{m}}\right)$.

In contrast to uncertainties related to interception, a pronounced seasonal variation characterises the uncertainties related to evapotranspiration. The reason why the uncertainties in evapotranspiration are higher in summer 2007 as compared to summer 2006 can be found in the mean summer temperatures of both years (Fig. 2). The mean temperature between April and September in 2006 was $13.17^{\circ} \mathrm{C}$. In comparison, a mean temperature of $14.16^{\circ} \mathrm{C}$ was observed in the same period in 2007. This difference of $1{ }^{\circ} \mathrm{C}$ leads to the observed increased uncertainties in $\mathrm{ET}_{\text {pot }}$. Thus, the results using temperature-based approaches for computing $\mathrm{ET}_{\text {pot }}$ show that
Fig. 6 The bars show the minimum and maximum percentage discrepancies between each model combination and the observed spring discharge

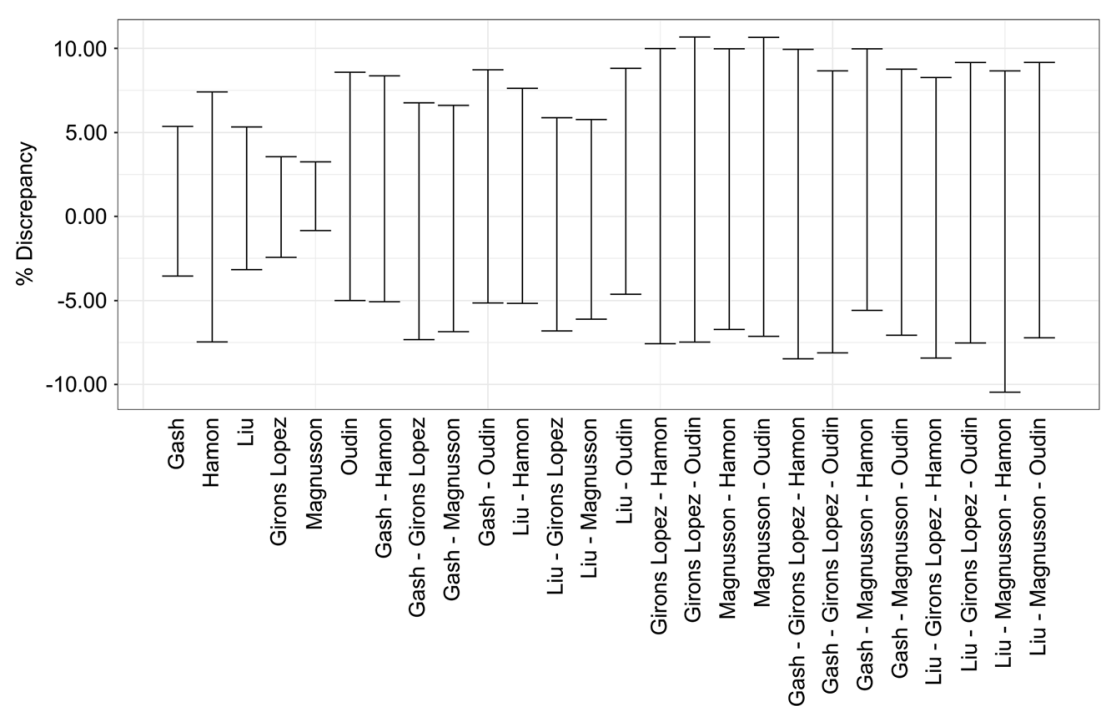



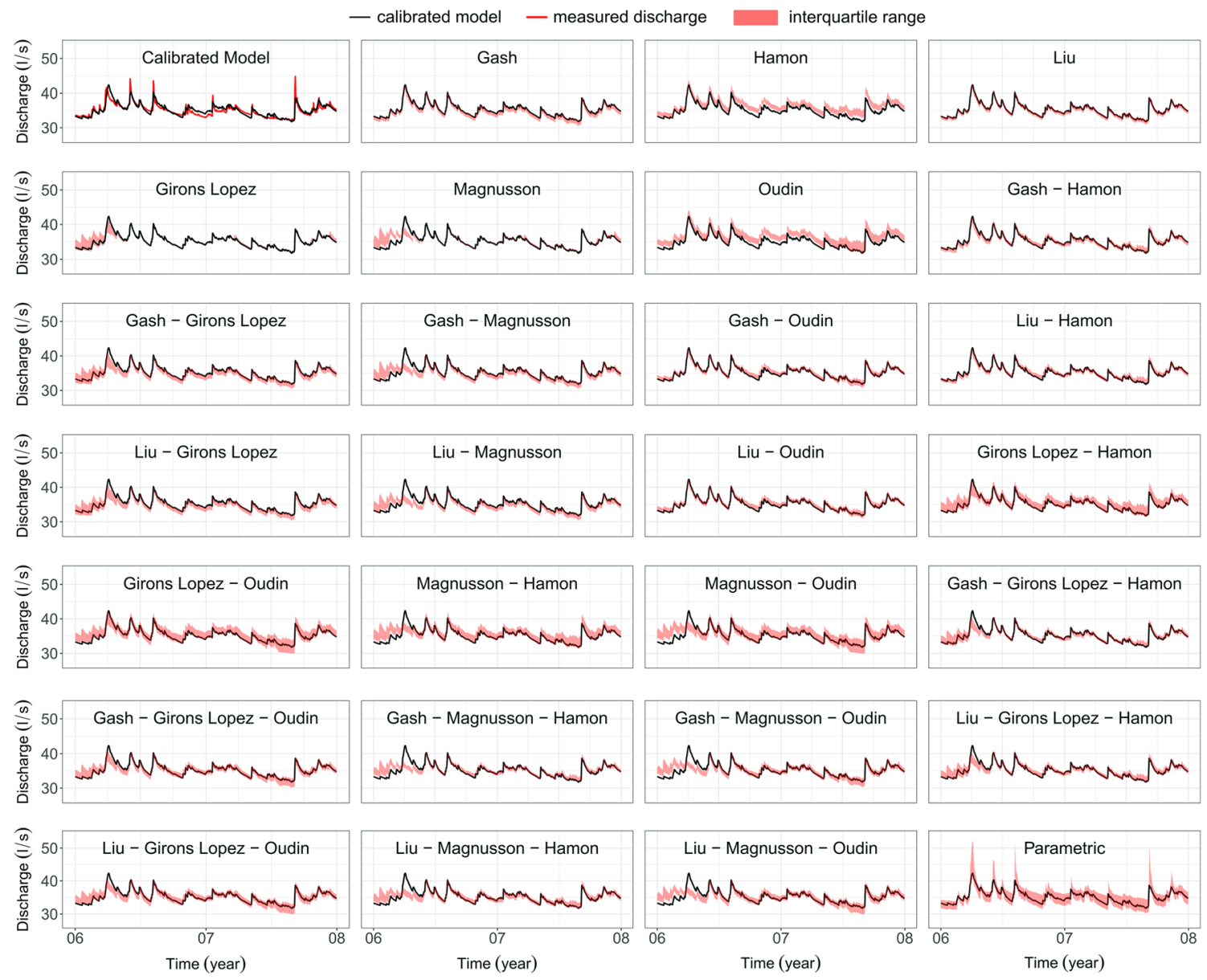

Fig. 7 Interquartile ranges of each model combination (red bands), including the results of the calibrated model from Bittner et al. (2018) (black line) and the parametric uncertainties obtained from Teixeira

Parente et al. (2019), which are shown in the bottom-right graph. The results of the calibrated model from Bittner et al. (2018) (black line) are also compared to the measured discharge (red line) in the top-left graph

the uncertainties of $\mathrm{ET}_{\text {pot }}$ increase with the available temperature for evapotranspiration. Given the fact that evapotranspiration related uncertainties can even reach the range of parametric uncertainties, e.g. in summer 2007, an appropriate representation of evapotranspiration is crucial to reasonably calculate the groundwater recharge as input for modeling a karst spring discharge in pre-alpine karst systems. Given the seasonal variation of uncertainties related to evapotranspiration, a reasonable representation of evapotranspiration for computing groundwater recharge is even more important during the summer period. This specific knowledge can guide researchers in gathering better field data when specific discharge conditions, e.g. mean and low flow conditions in summer, should be favored in model calibration. As recent studies highlighted the specific role of snowmelt for groundwater recharge in alpine and pre-alpine catchments, this study further investigates if this specific importance is also reflected in increased uncertainties in modeled spring discharge when snowmelt is
Fig. 8 Two examples to highlight that model input uncertainties do not necessarily increase with increasing hydrological process complexity. a Shows a case in which the input uncertainties increase with increasing process complexity. b Shows a case in which the input uncertainties can also partially decrease with increasing process complexity
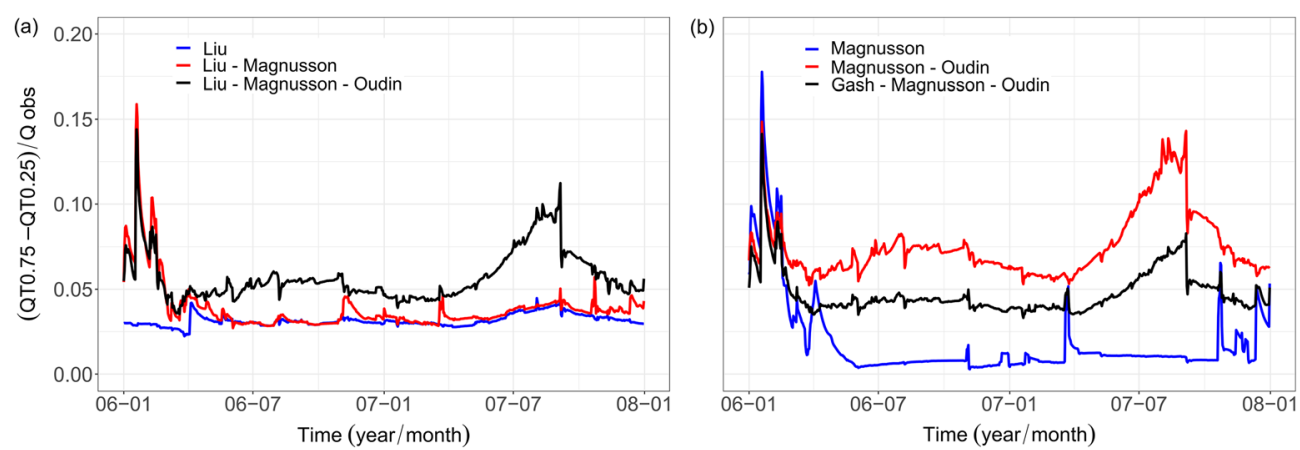
relevant. Similar to evapotranspiration, the results show a clear seasonal pattern of snowmelt related uncertainties. The differences in snowmelt uncertainties are more pronounced than for evapotranspiration. Large uncertainties in snowmelt are found in the winter 2005/2006, whereas snowmelt related uncertainties are even smaller than those related to interception in winter 2006-2007. Figure $2 b$ shows that in the winter season 2005-2006 the snow cover stayed for several months. Whereas, no long-lasting and pronounced snow cover was observed in the winter season 2006-2007. The same pattern of uncertainties can also be identified when considering snowmelt to be uncertain in combination with other processes, i.e. interception and evapotranspiration. Figure 9 shows the maximum interquartile range for all model combinations including uncertainties in snow processes, i.e. 18 model combinations, and for those which do not include these uncertainties, i.e. 8 model combinations. In case of uncertain snowmelt, the overall interquartile range significantly changes when snowmelt controls groundwater recharge and, thus, the modeled spring discharge (e.g. from January 2006 to May 2006). Moreover, while only considering snowmelt estimations to be uncertain does not lead to a significant increase in model output uncertainties in the evaporative season (Fig. 5), Fig. 9 shows that snowmelt estimations increase model output uncertainties in cases when snowmelt, interception and evapotranspiration are uncertain, e.g. in summer 2007. This can be explained by the fact that different processes can compensate for over- or underestimated water budgets of other processes. For example, an overestimation of the snowmelt can be compensated by an underestimation of the evapotranspiration. Summarizing, the results show that the higher uncertainties in snowmelt occur when the simulated spring discharge is controlled by snow processes. This highlights that the specific importance of snowmelt for groundwater recharge can be identified in the snowmelt related uncertainties when modeling a karst spring discharge. Hence, an erroneous assessment of snowmelt-related groundwater recharge can negatively affect the simulated spring discharge. On the contrary, the results do not exhibit a clear impact of uncertainties in snowmelt on the spring discharge during the evaporative season in summer, when the snowmelt related uncertainties are not significant $(<2 \%$ of the observed discharge, Fig. 5 ). In the specific case of the Kerschbaum LuKARS model, the baseflow storage of the dolomite-dominated aquifer has a high storage capacity and is not immediately affected by changing hydrometeorological conditions. However, this can be different in more limestone-dominated karst systems and requires further investigations.

Finally, the results of all model combinations highlight that considering more processes to be uncertain does not necessarily lead to an increase of the normalized interquartile range of modeled spring discharge. This is particularly true when considering evapotranspiration and snowmelt to be uncertain compared to considering also interception to be uncertain. These results highlight once more that two uncertain processes can compensate each other, leading to a reduction of the interquartile range of model outputs.

\section{Conclusion}

This study investigated how the input uncertainties of a lumped parameter model, i.e. LuKARS, vary temporally when applying the hydrologic model in a pre-alpine recharge area. Therefore, snowmelt, evapotranspiration and interception were computed with three different algorithms each. The resulting groundwater recharge was used as input for LuKARS considering each possible model combination and focusing on the uncertainties of each single process. Moreover, the input uncertainties imposed by each process

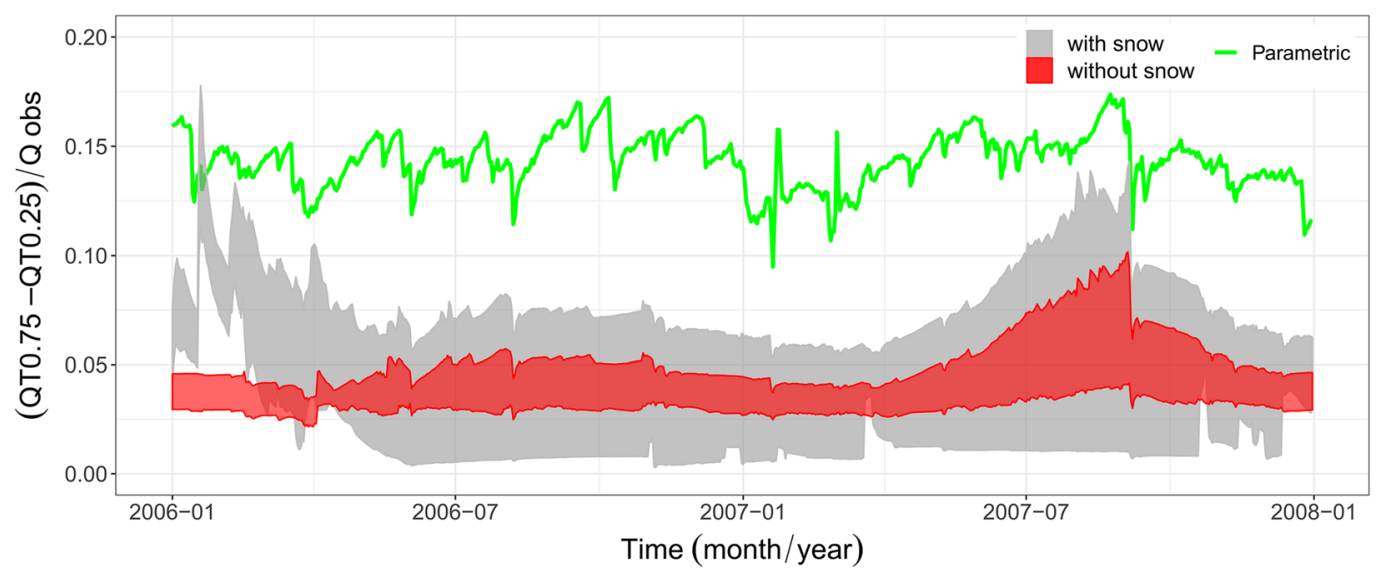

Fig. 9 Contribution of uncertainties related to snowmelt to the total LuKARS model input uncertainties. The two bands show the maximum interquartile ranges of the investigated model combinations that include uncertainties in snowmelt (grey) and of those which do not (red). An effect of snow process uncertainties can be observed throughout the years with a more pronounced impact during the winter 
were compared to the parametric uncertainties obtained in previous studies (Teixeira Parente et al. 2019).

No clear tendency towards increasing model output uncertainties can be identified when more hydrological input time series are considered to be uncertain. Indeed, it was found that with increasing number of uncertain input the interquartile range of the LuKARS model outputs can even decrease. This shows that two or more uncertain processes can compensate each other.

The results of this study further show that model input uncertainties show temporal variations depending on how much the groundwater recharge and the modeled spring discharge is controlled by one specific process, e.g. snowmelt and evapotranspiration. Thus, the results highlight that the importance of a specific process for groundwater recharge can be derived from the respective input uncertainties. Further, this research identified that uncertainties in snow processes can even be higher than parametric uncertainties.

This study investigated the time-dependent relevance of the model input uncertainties for pre-alpine conditions typical of Central Europe. A similar approach should be applied to ex- tend these results to karst catchments with different climate conditions and land uses. An intercomparison study could be based on the recently developed WoKaS database (Olarinoye et al. 2020). Moreover, it is of particular interest to apply the presented methodology to karst catchments characterized by different recharge processes. Thus, a comparison between catchments dominated by diffusive recharge, as the Kerschbaum springshed, and those dominated by point infiltration is suggested.

The knowledge gained from investigating temporally varying model input uncertainties can guide researchers and water managers in gaining relevant data needed for improving the reliability of hydrologic model results. In this case, e.g., the uncertainties in snowmelt could be reduced by implementing snow measurement stations in the recharge area. Moreover, the information on the temporal variability of model input uncertainties helps to derive which data are needed to improve the reliability of model output results during different times of year.

\section{Appendix 1}

Table 3 Overview of all model parameters used for the LuKARS model in the Kerschbaum spring recharge area (Bittner et al. 2018)

\begin{tabular}{|c|c|c|c|c|c|}
\hline Parameter & Hyd 1 & Hyd 2 & Hyd 3 & Hyd 4 & Parameter description \\
\hline \multicolumn{6}{|c|}{ Hydrotope-specific parameters } \\
\hline$E_{\text {ini }}[\mathrm{mm}]$ & 0 & 1 & 1 & 1 & Initial value of hydrotope storage \\
\hline$E_{\min }[\mathrm{mm}]^{\mathrm{a}}$ & 0 & 23 & 60 & 90 & Hydrotope storage under dry conditions \\
\hline$E_{\max }[\mathrm{mm}]^{\mathrm{a}}$ & 1 & 31 & 120 & 200 & Hydrotope storage under saturated conditions \\
\hline$E_{\mathrm{sec}}[\mathrm{mm}]^{\mathrm{a}}$ & 0 & 35 & 180 & 380 & Activation level for secondary springs \\
\hline$k_{\text {hyd }}\left[\mathrm{m}^{2} / \text { day }\right]^{\mathrm{a}}$ & 0 & 90 & 85 & 77 & Discharge parameter for quickflow \\
\hline$k_{\text {is }}[\mathrm{m} / \mathrm{mm} / \mathrm{day}]^{\mathrm{a}}$ & 0 & 0.02 & 0.0055 & 0.0025 & Discharge coeff. for recharge \\
\hline$k_{\mathrm{sec}}[\mathrm{m} / \mathrm{mm} / \text { day }]^{\mathrm{a}}$ & 0.9 & 0.095 & 0.026 & 0.022 & Secondary spring discharge coeff. \\
\hline$\alpha[-]^{\mathrm{a}}$ & 0 & 0.9 & 0.8 & 0.55 & Quickflow exponent \\
\hline$l_{\text {hyd }}[\mathrm{m}]$ & 550 & 1,600 & 900 & 960 & Mean hydrotope distance to spring \\
\hline$F\left[\mathrm{~mm} /\right.$ day $\left.{ }^{\circ} \mathrm{C}\right]$ & 4 & 4 & 4 & 4 & Melt factor in degree-day method \\
\hline$T_{\mathrm{f}}\left[{ }^{\circ} \mathrm{C}\right]$ & 0.5 & 0.5 & 0.5 & 0.5 & Temperature threshold for snowmelt \\
\hline$I_{\max }[\mathrm{mm}]$ & 0 & 5 & 5 & 5 & Max. interception of land use \\
\hline \multicolumn{6}{|c|}{ Baseflow storage parameters } \\
\hline \multicolumn{5}{|c|}{$k_{\mathrm{b}}[\mathrm{m} / \mathrm{mm} / \mathrm{day}]=0.00043$} & Baseflow discharge coefficient \\
\hline \multicolumn{5}{|l|}{$E_{\mathrm{b} \_ \text {ini }}[\mathrm{mm}]=2,900$} & Initial value of baseflow storage \\
\hline
\end{tabular}

${ }^{a}$ Indicates those parameters which were considered in the parameter uncertainty study in Teixeira Parente et al. (2019) 
Acknowledgements This research is a result of two projects, i.e. the UNMIX project (Uncertainties due to boundary conditions in predicting MIXing in groundwater), which is supported by Deutsche Forschungsgemeinschaft (DFG) through TUM International Graduate School for Science and Engineering (IGSSE), GSC 81, and the ROCKAT project (RObust Conceptualisation of KArst Transport), funded by DFG, HA 8113/6-1 and CH 981/6-1. The authors further refer to the Interreg Central Europe project boDEREC-CE, funded by ERDF. Author G. C. also acknowledges the support of the Stiftungsfonds für Umweltökonomie und Nachhaltigkeit GmbH (SUN). The water works in Waidhofen a.d. Ybbs kindly provided the orthophoto as well as the discharge, precipitation and temperature data recorded in the Kerschbaum spring recharge area.

Funding Open Access funding enabled and organized by Projekt DEAL. Funding for this research was provided by the Deutsche Forschungsgemeinschaft (DFG), in particular within the UNMIX project (Uncertainties due to boundary conditions in predicting MIXing in groundwater) of the TUM International Graduate School for Science and Engineering (IGSSE), GSC 81, and the ROCKAT project (RObust Conceptualisation of KArst Transport), funded by DFG, HA 8113/6-1 and $\mathrm{CH} 981 / 6-1$.

\section{Declarations}

Conflict of interest On behalf of all authors, the corresponding author states that there is no conflict of interest.

Open Access This article is licensed under a Creative Commons Attribution 4.0 International License, which permits use, sharing, adaptation, distribution and reproduction in any medium or format, as long as you give appropriate credit to the original author(s) and the source, provide a link to the Creative Commons licence, and indicate if changes were made. The images or other third party material in this article are included in the article's Creative Commons licence, unless indicated otherwise in a credit line to the material. If material is not included in the article's Creative Commons licence and your intended use is not permitted by statutory regulation or exceeds the permitted use, you will need to obtain permission directly from the copyright holder. To view a copy of this licence, visit http://creativecommons.org/licenses/by/4.0/.

\section{References}

Ahmadi A, Nasseri M, Solomatine DP (2019) Parametric uncertainty assessment of hydrological models: coupling UNEEC-P and a fuzzy general regression neural network. Hydrol Sci J 64:1080-1094

Alduchov OA, Eskridge RE (1996) Improved Magnus form approximation of saturation vapor pressure. J Appl Meteorol 35:601-609

Almorox J, Quej VH, Martí P (2015) Global performance ranking of temperature-based approaches for evapotranspiration estimation considering Köppen climate classes. J Hydrol 528:514-522

Arnold JG, Srinivasan R, Muttiah RS, Williams JR (1998) Large area hydrologic modeling and assessment part I: model development. J Am Water Resour Assoc 34:73-89

Bittner D, Narany TS, Kohl B, Disse M, Chiogna G (2018) Modeling the hydrological impact of land use change in a dolomite-dominated karst system. J Hydrol 567:267-279

Bittner D, Rychlik A, Klöffel T, Leuteritz A, Disse M, Chiogna G (2020a) A GIS-based model for simulating the hydrological effects of land use changes on karst systems: the integration of the LuKARS model into FREEWAT. Environ Model Softw 127:104682
Bittner D, Parente MT, Mattis S, Wohlmuth B, Chiogna G (2020b) Identifying relevant hydrological and catchment properties in active subspaces: an inference study of a lumped karst aquifer model. Adv Water Resour 135:103472

Bittner D, Engel M, Wohlmuth B, Labat D, Chiogna G (2021) Temporal scale-dependent sensitivity analysis using discrete wavelet transform and active subspaces. Water Resour Res. (under review) https://doi.org/10.1002/essoar.10503923.1

Braun L, Renner C (1992) Application of a conceptual runoff model in different physiographic regions of Switzerland. Hydrol Sci J 37: 217-231

Breinl K (2016) Driving a lumped hydrological model with precipitation output from weather generators of different complexity. Hydrol Sci J 61:1395-1414

Butts MB, Payne JT, Kristensen M, Madsen H (2004) An evaluation of the impact of model structure on hydrological modelling uncertainty for streamflow simulation. J Hydrol 298:242-266

Calder IR (1996) Dependence of rainfall interception on drop size: 1. development of the two-layer stochastic model. J Hydrol 185:363378

Colaizzi PD, Kustas WP, Anderson MC, Agam N, Tolk JA, Evett SR, Howell TA, Gowda PH, O'Shaughnessy SA (2012) Two-source energy balance model estimates of evapotranspiration using component and composite surface temperatures. Adv Water Resour 50: 134-151

Cukier RI, Levine HB, Shuler KE (1978) Nonlinear sensitivity analysis of multiparameter model systems. J Comput Phys 26:1-42

Doummar J, Hassan Kassem A, Gurdak JJ (2018) Impact of historic and future climate on spring recharge and discharge based on an integrated numerical modelling approach: application on a snowgoverned semi-arid karst catchment area. J Hydrol 565:636-649

DVWK (1996) Ermittlung der Verdunstung von Land- und Wasserflächen [Determination of evaporation from land and water]. DVWK-Merkblatt 238/1996, DWA,German Association for Water, Wastewater and Waste, Hennef, Germany

Fandel C, Ferré T, Chen Z, Renard P, Goldscheider N (2020) A model ensemble generator to explore structural uncertainty in karst systems with unmapped conduits. Hydrogeol J 414-415:516

Fleury P, Plagnes V, Bakalowicz M (2007) Modelling of the functioning of karst aquifers with a reservoir model: application to Fontaine de Vaucluse (south of France). J Hydrol 345:38-49

Garrigues S, Olioso A, Calvet JC, Martin E, Lafont S, Moulin S, Chanzy A, Marloie O, Buis S, Desfonds V, Bertrand N, Renard D (2015) Evaluation of land surface model simulations of evapotranspiration over a 12-year crop succession: impact of soil hydraulic and vegetation properties. Hydrol Earth Syst Sci 19:3109-3131

Gash JHC, Lloyd CR, Lachaud G (1995) Estimating sparse forest rainfall interception with an analytical model. J Hydrol 170:79-86

GBA (2021) Geologische Bundesländerkarten [Geological maps of the federal states]. Geologische Bundesanstalt Österreich, Vienna

Girons Lopez M, Vis MJP, Jenicek M, Griessinger N, Seibert J (2020) Assessing the degree of detail of temperature-based snow routines for runoff modelling in mountainous areas in Central Europe. Hydrol Earth Syst Sci 24:4441-4461

Guinot V, Savéan M, Jourde H, Neppel L (2015) Conceptual rainfallrunoff model with a two-parameter, infinite characteristic time transfer function. Hydrol Process 29:4756-4778

Gupta A, Govindaraju RS (2019) Propagation of structural uncertainty in watershed hydrologic models. J Hydrol 575:66-81

Hall RL (2003) Interception loss as a function of rainfall and forest types: stochastic modelling for tropical canopies revisited. J Hydrol 280:112

Hamon WR (1961) Estimating potential evapotranspiration. J Hydraul Div Proc ASCE 87:107-120

Hartmann A, Wagener T, Rimmer A, Lange J, Brielmann H, Weiler M (2013) Testing the realism of model structures to identify karst 
system processes using water quality and quantity signatures. Water Resour Res 49:3345-3358

Hartmann A, Goldscheider N, Wagener T, Lange J, Weiler M (2014a) Karst water resources in a changing world: review of hydrological modeling approaches. Rev Geophys 52:218-242

Hartmann A, Mudarra M, Andreo B, Marín A, Wagener T, Lange J (2014b) Modeling spatiotemporal impacts of hydroclimatic extremes on groundwater recharge at a Mediterranean karst aquifer. Water Resour Res 50:6507-6521

Hartmann A, Gleeson T, Wada Y, Wagener T (2017) Enhanced groundwater recharge rates and altered recharge sensitivity to climate variability through subsurface heterogeneity. Proc Natl Acad Sci U S A 114:2842-2847

Henson WR, Rooij R, Graham W (2018) What makes a first-magnitude spring? Global sensitivity analysis of a speleogenesis model to gain insight into karst network and spring genesis. Water Resour Res 54: $7417-7434$

Herrero J, Polo MJ, Moñino A, Losada MA (2009) An energy balance snowmelt model in a Mediterranean site. J Hydrol 371:98-107

Hottelet C, Blažková Š, Bičík M (1994) Application of the ETH snow model to three basins of different character in Central Europe. Hydrol Res 25:113-128

Hu J, Chen S, Behrangi A, Yuan H (2019) Parametric uncertainty assessment in hydrological modeling using the generalized polynomial chaos expansion. J Hydrol 579:124158

Jódar J, González-Ramón A, Martos-Rosillo S, Heredia J, Herrera C, Urrutia J, Caballero Y, Zabaleta A, Antigüedad I, Custodio E, Lambán LJ (2020) Snowmelt as a determinant factor in the hydrogeological behaviour of high mountain karst aquifers: the Garcés karst system, Central Pyrenees (Spain). Sci Total Environ 748:141363

Kavetski D, Kuczera G, Franks SW (2006) Bayesian analysis of input uncertainty in hydrological modeling: 2. application. Water Resour Res 42:1015

Lee G, Tachikawa Y, Takara K (2011) Comparison of model structural uncertainty using a multi-objective optimisation method. Hydrol Process 25:2642-2653

Liu S (2001) Evaluation of the Liu model for predicting rainfall interception in forests world-wide. Hydrol Process 15:2341-2360

Liu M, Xu X, Sun AY, Luo W, Wang K (2018) Why do karst catchments exhibit higher sensitivity to climate change? Evidence from a modified Budyko model. Adv Water Resour 122:238-250

Liu Y, Wagener T, Hartmann A (2021) Assessing streamflow sensitivity to precipitation variability in karst-influenced catchments with unclosed water balances. Water Resour Res 57:177. https://doi.org/10. 1029/2020WR028598

Lucianetti G, Penna D, Mastrorillo L, Mazza R (2020) The role of snowmelt on the spatio-temporal variability of spring recharge in a Dolomitic Mountain group, Italian Alps. Water 12:2256

Magnusson J, Gustafsson D, Hüsler F, Jonas T (2014) Assimilation of point SWE data into a distributed snow cover model comparing two contrasting methods. Water Resour Res 50:7816-7835

Markart G, Kohl B, Perzl F (2006) Der Bergwald und seine hydrologische Wirkung: eine unterschätzte Größe [The mountain forest and its hydrological effect: an underestimated variable]? In: LWF Wissen. Wald - Schutz vor Hochwasser? Beiträge zum Symposium, 27 April 2006, pp 34-43

Marks D, Domingo J, Susong D, Link T, Garen D (1999) A spatially distributed energy balance snowmelt model for application in mountain basins. Hydrol Process 13:1935-1959

Martinec J (1960) The degree-day factor for snowmelt runoff forecasting. IUGG General Assembly of Helsinki, Commission of Surface Waters, IAHS, Wallingford, UK, pp 468-477

Mazzilli N, Guinot V, Jourde H (2012) Sensitivity analysis of conceptual model calibration to initialisation bias: application to karst spring discharge models. Adv Water Resour 42:1-16
McMillan H, Krueger T, Freer J (2012) Benchmarking observational uncertainties for hydrology: rainfall, river discharge and water quality. Hydrol Process 26:4078-4111

Moussu F, Oudin L, Plagnes V, Mangin A, Bendjoudi H (2011) A multiobjective calibration framework for rainfall-discharge models applied to karst systems. J Hydrol 400:364-376

Narany TS, Bittner D, Disse M, Chiogna G (2019) Spatial and temporal variability in hydrochemistry of a small-scale dolomite karst environment. Environ Earth Sci 78:1-17

Nerantzaki SD, Hristopulos DT, Nikolaidis NP (2020) Estimation of the uncertainty of hydrologic predictions in a karstic Mediterranean watershed. Sci Total Environ 717:137131

Olarinoye T, Gleeson T, Marx V, Seeger S, Adinehvand R, Allocca V, Andreo B, Apaéstegui J, Apolit C, Arfib B, Auler A, Bailly-Comte V, Barberá JA, Batiot-Guilhe C, Bechtel T, Binet S, Bittner D, Blatnik M, Bolger T, Brunet P, Charlier J-B, Chen Z, Chiogna G, Coxon G, de Vita P, Doummar J, Epting J, Fleury P, Fournier M, Goldscheider N, Gunn J, Guo F, Guyot JL, Howden N, Huggenberger P, Hunt B, Jeannin P-Y, Jiang G, Jones G, Jourde H, Karmann I, Koit O, Kordilla J, Labat D, Ladouche B, Liso IS, Liu Z, Maréchal J-C, Massei N, Mazzilli N, Mudarra M, Parise M, Pu J, Ravbar N, Sanchez LH, Santo A, Sauter M, Seidel J-L, Sivelle V, Skoglund RØ, Stevanovic Z, Wood C, Worthington S, Hartmann A (2020) Global karst springs hydrograph dataset for research and management of the world's fastest-flowing groundwater. Sci Data 7:59

Ollivier C, Mazzilli N, Olioso A, Chalikakis K, Carrière SD, Danquigny C, Emblanch C (2020) Karst recharge-discharge semi distributed model to assess spatial variability of flows. Sci Total Environ 703: 134368

Ollivier C, Olioso A, Carrière SD, Boulet G, Chalikakis K, Chanzy A, Charlier J-B, Combemale D, Davi H, Emblanch C, Marloie O, Martin-StPaul N, Mazzilli N, Simioni G, Weiss M (2021) An evapotranspiration model driven by remote sensing data for assessing groundwater resource in karst watershed. Sci Total Environ 781: 146706. https://doi.org/10.1016/j.scitotenv.2021.146706

Oudin L, Hervieu F, Michel C, Perrin C, Andréassian V, Anctil F, Loumagne $C$ (2005) Which potential evapotranspiration input for a lumped rainfall-runoff model? J Hydrol 303:290-306

Patil A, Deng Z-Q, Malone RF (2011) Input data resolution-induced uncertainty in watershed modelling. Hydrol Process 25:2302-2312

Penman HL (1948) Natural evaporation from open water, hare soil and grass. Proc R Soc Lond A Math Phys Sci 193:120-145

Pianosi F, Sarrazin F, Wagener T (2015) A MATLAB toolbox for global sensitivity analysis. Environ Model Softw 70:80-85

Rojas R, Feyen L, Dassargues A (2008) Conceptual model uncertainty in groundwater modeling: combining generalized likelihood uncertainty estimation and Bayesian model averaging. Water Resour Res 44: 655

Sarrazin F, Hartmann A, Pianosi F, Rosolem R, Wagener T (2018) V2Karst V1.1: a parsimonious large-scale integrated vegetationrecharge model to simulate the impact of climate and land cover change in karst regions. Geosci Model Dev 11:4933-4964

Seibert J (1997) Estimation of parameter uncertainty in the HBV model. Hydrol Res 28:247-262

Sivelle V, Jourde H (2020) A methodology for the assessment of groundwater resource variability in karst catchments with sparse temporal measurements. Hydrogeol J 40:543

Sivelle V, Labat D, Mazzilli N, Massei N, Jourde H (2019) Dynamics of the flow exchanges between matrix and conduits in karstified watersheds at multiple temporal scales. Water 11:569

Sivelle V, Jourde H, Bittner D, Mazzilli N, Tramblay Y (2021) Assessment of the relative impacts of climate changes and anthropogenic forcing on spring discharge of a Mediterranean karst system. J Hydrol 598:126396 
Teixeira Parente M, Bittner D, Mattis SA, Chiogna G, Wohlmuth B (2019) Bayesian calibration and sensitivity analysis for a karst aquifer model using active subspaces. Water Resour Res 55:7086-7107

Thornthwaite CW (1948) An approach toward a rational classification of climate. Geogr Rev:55-94

Vrugt JA, ter Braak CJF, Clark MP, Hyman JM, Robinson BA (2008) Treatment of input uncertainty in hydrologic modeling: doing hydrology backward with Markov chain Monte Carlo simulation. Water Resour Res 44:937
Wagener T, McIntyre N, Lees MJ, Wheater HS, Gupta HV (2003)

Towards reduced uncertainty in conceptual rainfall-runoff modelling: dynamic identifiability analysis. Hydrol Process 17:455-476

Publisher's note Springer Nature remains neutral with regard to jurisdictional claims in published maps and institutional affiliations. 